\title{
Analysis of measurement points sensitivity of vibration signals on the stand of jet engine
}

\begin{abstract}
The diagnostic testing of internal combustion engine can be made by using working processes and methods which take advantage of leftover processes. Working processes give information about general condition of internal combustion engine. Leftover processes give information about condition of particular subassemblies and kinematic couples; hence they are used as autonomous processes or as processes supporting other diagnostic methods. Methods based on analysis of vibrations and noise changes to determine technical condition of object are named as vibroacoustic diagnostics. In papers about vibroacoustic diagnostics of engine, problems connected with difficulty to select test point and to define diagnostic parameters containing essential information about engine's condition, are most often omitted. Selection of engine's working parameters and conditions of taking measurements or recording vibration signal are usually based on references, researcher's experience or intuition. General assumptions about taking measurements of signal closest to its source are most often used. This paper presents a new approach to vibroacoustic diagnostics of jet engine. Selection of measurement points of vibration signals on the basis of tests stand results was suggested and perform a sensitivity analysis of measurement points on the engine support.
\end{abstract}

Key words: vibration signal, jet engine

\section{Introduction}

In the capacity of drive units in the aircraft among other things the jet engines of high power rating are used. Diagnosing of their technical condition enables to carry out an overhaul policy conditioned by technical condition, to prevent most of unplanned outages and by detecting defects in early stage, to decrease significantly the scope and the cost of overhaul and service. Safety of transportation and their timelines constitute a separate issue.

To assess technical condition and working conditions (functional and operation parameters) of combustion engine, parameters and characteristics of vibration signal generated by combustion engine [1-3] are more and more often used. However, receiving from vibrations diagnostically useful information is not easy. It is difficult to identify and to deduct the technical or working condition of engine's part or subassembly on the basis of commonly used parameters and characteristics of vibroacoustic signal (VA), stems, among others, from complex nature of vibrations generated by engine, processes proceeding inside, coexistence of many sources of vibrations and complex kinetics.

This study hereafter will show the problem of choosing on the engine support the point of acquisition of the vibration signals for diagnostic testing (for the aspect engine power assessing).

\section{Choosing the measurement point of the vibration signals}

The following values describe working processes used in diagnostic testing of combustion engines: power, torque, reaction torque, instantaneous angular speed and turning angle of crankshaft etc. They are used as conceptualized parameters of technical condition of an engine. To assess technical condition of combustion engine, parameters of accompanying processes, working processes and parameters of processes used in nondestructive tests (e.g. ultrasounds) are used as a vector signal.
Parameters of accompanying processes (vibrations, noise, thermal processes, wear etc.) are used to diagnose detailed technical condition of engine and to localize failures. In diagnostic testing of jet engine, vibroacoustic processes (vibrations, noise) are the often used accompanying processes.

Because of placing the vibration transducers has strong influence on the results received after diagnostic signals analysis, in the course of drawing up a method for the diagnostic testing the important thing is choosing the point of vibration signal acquisition. In extreme case the place of vibration measurement improperly chosen might give wrong conclusions about the technical condition of jet engine.

\section{Research methodology}

Jet engine F100-PW-229 were the research object. This engine is used, among others, to drive aircrafts F16. It is an afterburning turbofan engine. Research concerning sensitivity of measurements points was carried out according to active experiment. Active experiment consists in purposeful change of input or disturbing parameters and observing influence of those changes on input parameters. Power of engine was taken as input parameter and vibration accelerations of jet engine's test stand are taken as output parameters.

The vibration transducers type 4513 and $8344[7,8]$ made by Brüel \& Kjær company were chosen following the instructions comprised in the study $[4,5]$ and their frequency band was up to $10 \mathrm{kHz}$ (for 4514 ) and up to $3 \mathrm{kHz}$ (for 8344). In the course of diagnostic testing the signals in the band range from $0.1 \mathrm{~Hz}$ to $51.2 \mathrm{kHz}$ were recorded. The sampling frequency was adjusted to the value of $131072 \mathrm{~Hz}$ and the accelerometers were mounted on the engine support by glue. To choose the places of measurement a principle that the transducer should be put in the place accessible and closest to the area where the working engine generate the vibration signals was taken $[1,6]$.To recording the vibration signals three pieces of the vibration converters (P1, P2, P3) 
were used. Measurements were made for the following power settings: Idle, Middle (Mid), Afterburner min (AB Min), Afterburner max (AB Max).

Figure 1 presents a view the engine on the test stand while Figure 2 - the spatial orientation of the transducers for vibration measurements and the places of their mounting on tested object. To recording the vibration signals a MultiAnalyzer PULSE made by the Brüel \& Kjær company was used. The view of the measurement equipment on the test stand is shown in Figure 3.
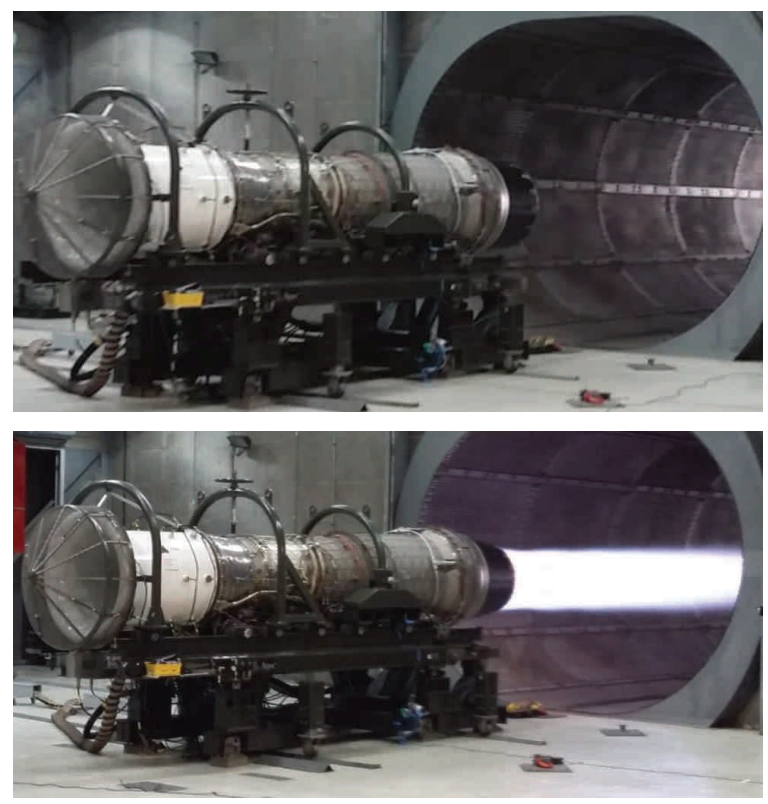

Fig. 1. View of the engine F100-PW-229 on the test stand

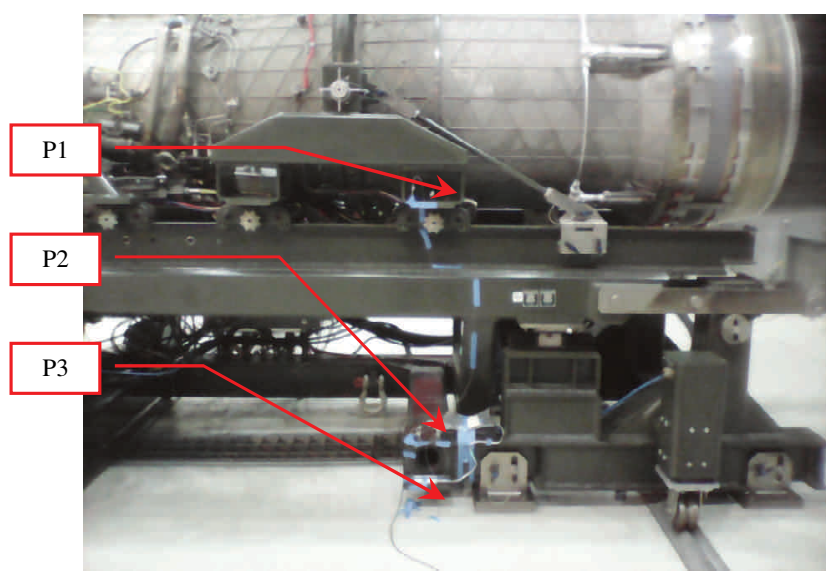

Fig. 2. Distribution of acceleration transducers on the test stand, engine F100-PW-229
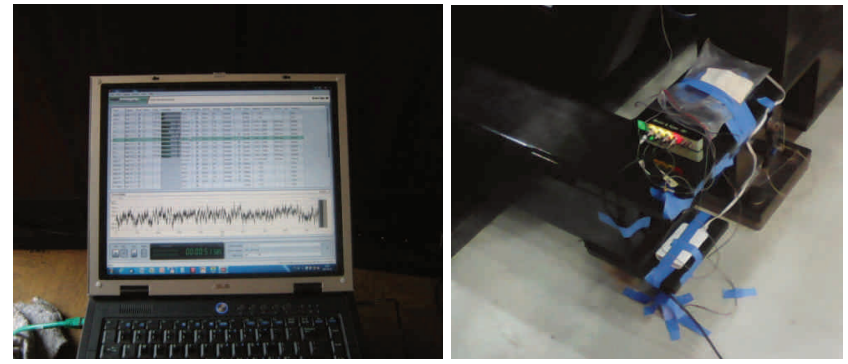

Fig. 3. View of the measurement equipment on the test stand
The device shown in Figure 3 enables the registration of the quick-changeable runs parallel on 17 ducts with the dynamics up to $160 \mathrm{~dB}$.

\section{Analysis of test results}

To make selection of the best point of signal acquisition for assessing the power of engine, the tests of the engine stand were made and they consisted in impacting of the engine power for the test stand. To eliminate the casual errors and to obtain the averaging result, the operation described above was repeated several times. The aim was to determine such a vibration signals measurement place which would allow to make assessment of the impacting change of engine power for vibration signal. The analysis of the signals recorded were made in PULSE REFLEX [9] environment. The used software enabled to carry out an analysis of three signals at the same time. Such an analysis variant gave opportunity to determine the influence of the dynamical impacts in on the signals synchronously recorded in three different measurement points.

Selected tests results for determining the acquisition point of the vibration acceleration signals are shown in figures 4-7. Figure 4 shows the time histories of vibration signals for different measurement points with markers defining state of engine power during test.

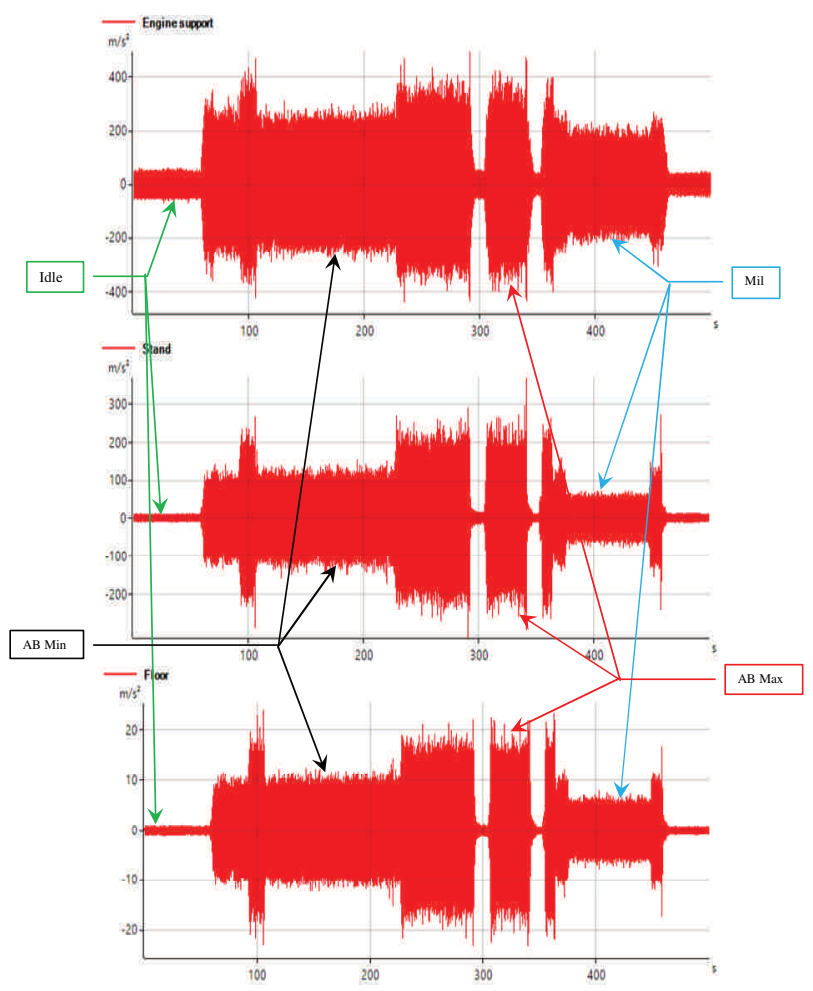

Fig. 4. Time histories of vibration signals for different measurement points

Figure 5 shows the averaging amplitude spectrums of the vibration acceleration signals synchronously recorded in three different measurement points. The demonstrated spectrums are the results of the analysis of vibration signals being outcome of the different power settings. In this figure the results are grouped by terms of settings power. 


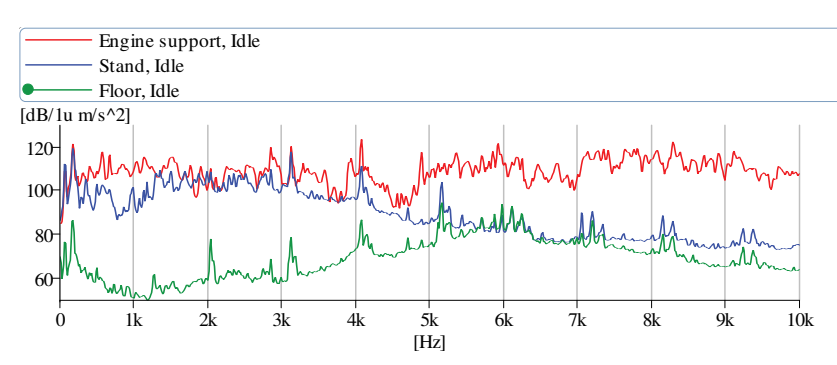

- Engine support, Mil
Stand, Mil
Floor, Mil
[dB/lu m/s^2]
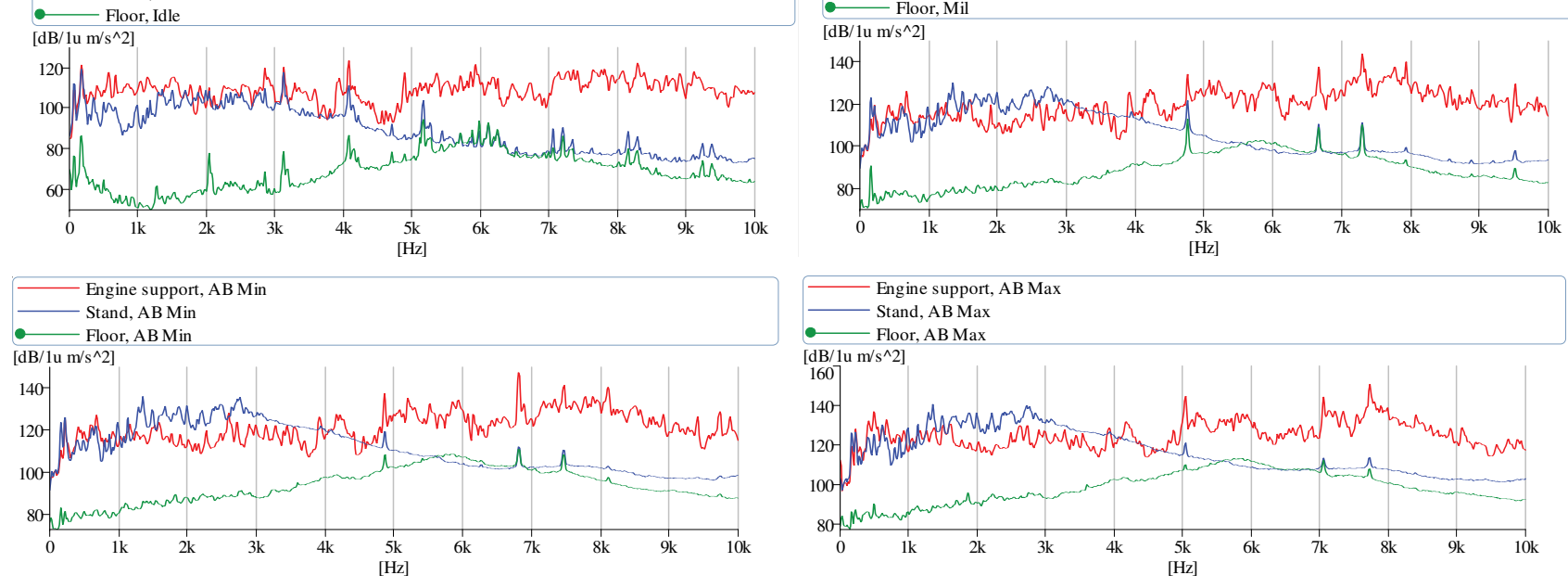

Fig. 5. The averaging amplitude spectrums of the vibration accelerations
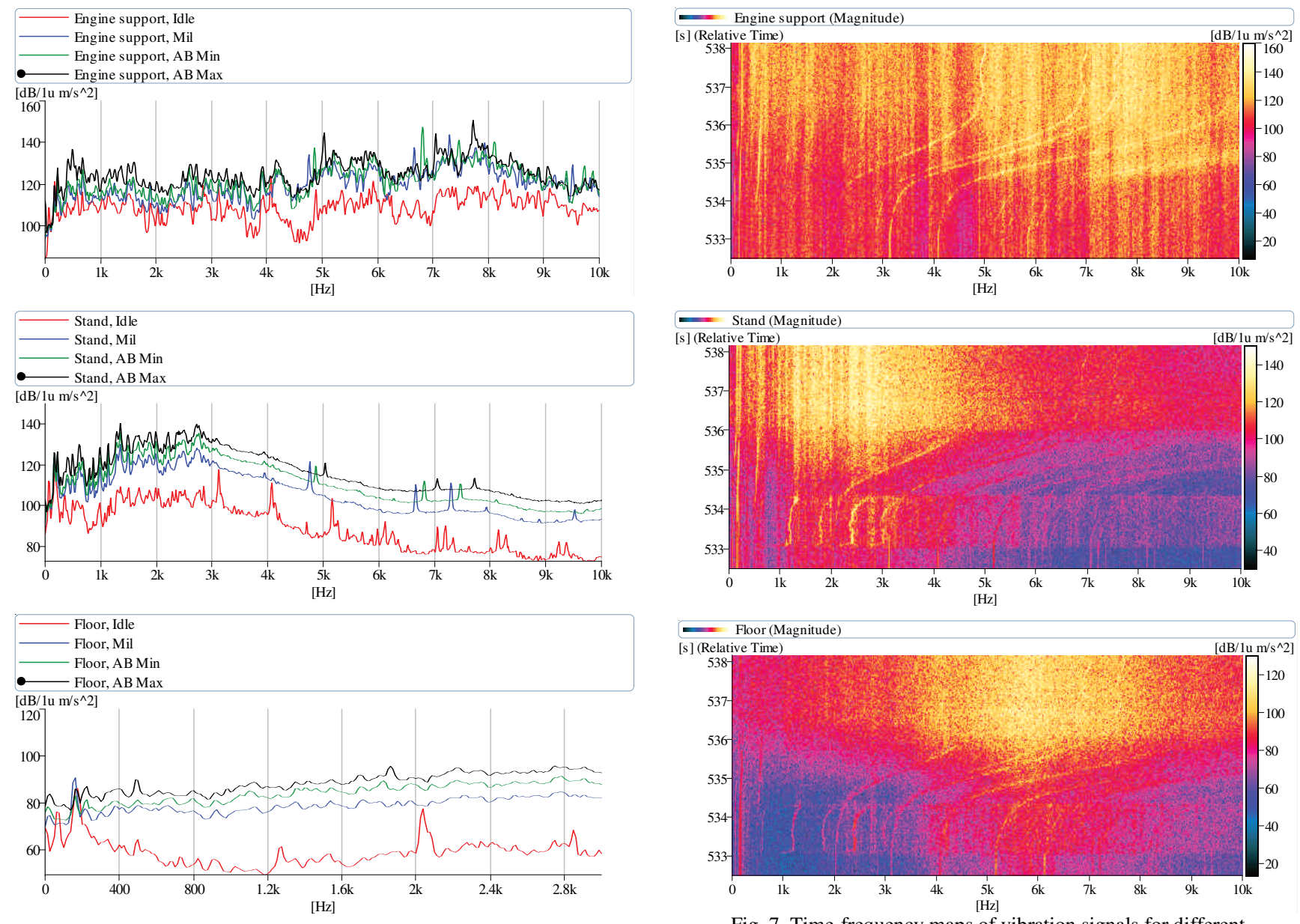

Fig. 6. The averaging amplitude spectrums of the vibration accelerations

Figure 6 shows the average amplitude spectrum of vibration acceleration signals recorded at three different measurement points. In this illustration the results are grouped by measurement points.

The time-frequency analysis for the motor acceleration test from Idle to $\mathrm{AB}$ Max is shown in Figure 7. Visible frequency changes in time are the result of changes in the revolution speed of the engine shaft.

Fig. 7. Time-frequency maps of vibration signals for different measurement points

From the characteristics shown in Figures 4-7, it appears that to assess the action of power in an engine tested, the best thing is to apply the point $\mathrm{P} 1$ or $\mathrm{P} 2$ because they are characterized by the better dynamics than point P3. Measurement point $\mathrm{P} 1$ is better than P2, for analysis concerning with natural frequencies of system. Whereas point $\mathrm{P} 2$ is good to frequencies analysis related with 
kinematics. To make an assessment of the engine power, point P3 is much less useful.

\section{Conclusion}

This paper shows a method which supports the choosing of the vibration signals acquisition points, it is based on an analysis of the test signals. This paper demonstrated that in the course of working out the test method is not enough to consider only the specialist literature and/or the some researcher's experience.

In described case all three measurement points met the requirements described in specialist literature, i.e. they were placed closest to the vibration source and they were easy accessible. However, to make an assessment of the power of engine, by the frequency characteristics analysis on the basis of test signals, point P1 and P2 was chosen.
Through the analysis of the presented test results it was found that the point of acquisition of the vibration signals, described as P3 should not be used for making an assessment of the engine power, because it is characterized by the low dynamics in the changes in the characteristics of spectrum test signals.

It is possible to use measurement point $\mathrm{P} 3$ for making a diagnosis of the other processes in jet engine. However, it is necessary first to make tests for proving the usefulness of this measurement point for a diagnostic testing.

\section{Acknowledgements}

This work was supported by Statutory Activities fund of the Institute of Combustion Engines and Transport, PUT (PL) 05/52/DSPB/0259.

\section{Bibliography}

[1] NIZIŃSKI, S., MICHALSKI, R. Diagnostyka obiektów technicznych. Biblioteka Problemów Eksploatacji Polskie Towarzystwo Diagnostyki Technicznej. Katedra Eksploatacji Pojazdów i Maszyn Wydziału Nauk Technicznych Uniwersytetu Warmińsko-Mazurskiego w Olsztynie. Instytut Technologii Eksploatacji w Radomiu, 2002.

[2] CZECHYRA, B., SZYMAŃSKI, G.M., TOMASZEWSKI, F. Assessment of camvalves clearance in internal combustion engine based on parameters of vibration methodological assumption. Combustion Engines. 2004, 118(1).

[3] SZYMAŃSKI, G.M. Analiza możliwości zastosowania wybranych charakterystyk sygnału drganiowego do

\footnotetext{
Grzegorz M. Szymański, DSc., DEng. - Faculty of Machines and Transport at Poznań University of Technology.

e-mail: Grzegorz.M.Szymanski@put.poznan.pl
}

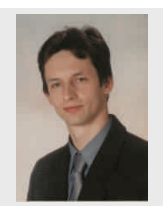

diagnostyki silnika spalinowego. Rozprawa doktorska. Politechnika Poznańska, Poznań 2005.

[4] OSIECKI, J., ZIEMBA, S. Podstawy pomiarów drgań mechanicznych. Państwowe Wydawnictwo Naukowe. Warszawa 1968.

[5] SERRIDGE, M., LICHT, T.R. Piezoelectric accelerometers and vibration preamplifiers. Brüel \& Kjar. 1987.

[6] ŻÓŁTOWSKI, B., ĆWIK, Z. Leksykon diagnostyki technicznej. ATR. Bydgoszcz 1996.

[7] 4513A - Piezoelectric IEPE accelerometer. 2017. www.bksv. com/media/doc/Bp2065.pdf.

[8] 8344A - Piezoelectric TEDS accelerometer. 2017 www.bksv. com/en/products/transducers/vibration/Vibration-transducers/ accelerometers/8344.

[9] Pulse Analysis Software. 2017. www.bksv.com/en/ products/PULSE-analysis-software.

Capt. Wojciech Misztal, DEng. - 31st Tactical Air

Base, Poznan-Krzesiny.

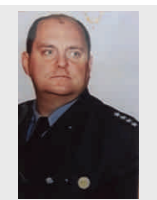

